\title{
Dust exposure and mortality in an American factory using chrysotile, amosite, and crocidolite in mainly textile manufacture
}

\author{
A D MCDONALD, ${ }^{1} \mathrm{~J}$ S FRY,${ }^{1}$ A J WOOLLEY, ${ }^{2}$ AND J C MCDONALD ${ }^{2}$ \\ From the Department of Epidemiology, ${ }^{1}$ St Mary's Hospital Medical School, and the TUC Centenary Institute \\ of Occupational Health, ${ }^{2}$ London School of Hygiene and Tropical Medicine, London, UK
}

ABSTRACT This report describes the second in a series of three parallel cohort studies of asbestos factories in South Carolina, Pennsylvania, and Connecticut to assess the effects of mineral fibre type and industrial process on mortality from malignant mesothelioma, respiratory cancer, and asbestosis. In the present plant (in Pennsylvania) mainly chrysotile, with some amosite and a small amount of crocidolite, were used primarily in textile manufacture. Of a cohort of 4137 men comprising all those employed 1938-59 for at least a month, 97\% were traced. By the end of $1974,1400(35 \%)$ had died, 74 from asbestosis and 70 from lung cancer. Mesothelioma was mentioned on the certificate in 14 deaths mostly coded to other causes. All these deaths occurred after 1959, and there were indications that additional cases of mesothelioma may have gone unrecognised, especially before that date. The exposure for each man was estimated in terms of duration and dust concentration in millions of dust particles per cubic foot (mpcf) from available measurements. Analyses were made both by life table and case referent methods. The standardised mortality ratio for respiratory cancer for the whole cohort was $105 \cdot 0$, but the risk rose linearly from 66.9 for men with less than 10 mpcf.y to 416.1 for those with 80 mpcf.y or more. Lines fitted to relative risks derived from SMRs in this and the textile plant studied in South Carolina were almost identical in slope. This was confirmed by case referent analysis. These findings support the conclusion from the South Carolina study that the risk of lung cancer in textile processing is very much greater than in chrysotile production and probably than in the friction products industry. The much greater risk of mesothelioma from exposure to processes in which even quite small quantities of amphiboles were used was also confirmed.

Cohort mortality studies were conducted simultaneously in three American plants to clarify the effect of mineral type of asbestos and of processing, as distinct from production, on mortality from malignant mesothelioma, lung cancer, and asbestosis. Preliminary reports describing results by duration of employment in all three plants ${ }^{1}$ and detailed exposureresponse findings in one of them-a textile plant that used only chrysotile ${ }^{2}$ - have been published. This report concerns a second plant which manufactured mainly textiles but also friction products and packings, many of which were made from the textile products. In addition to chrysotile, some amphibole asbestos (amosite and crocidolite) was also used. In

Received 15 February 1983 Accepted 7 March 1983. the third plant friction materials and packings were made from chrysotile only and no textiles were manufactured. ${ }^{3}$ The plant dealt with in the present report has been the subject of two previous studies $^{45}$; in both, excess mortality was reported from chronic respiratory disease, lung cancer, and malignant mesothelioma. In neither study was exposure estimated other than by duration of employment. In the present study the cohort was much larger, and individual dust exposures were estimated from environmental measurements made in the work place.

\section{Materials and methods}

The workforce at the plant averaged 1200 men and women between the late 1930s and 1975; before then it was rather smaller. Social security numbers 
were allocated in 1937. Details of all those employed before 1 January 1959 for at least one calendar month, with a recorded social security number, were submitted to the United States Social Security Administration. Those whose numbers and names were consistent with the administration's records comprised the cohort. The cohort therefore fell into two groups: (a) all those first employed after 1937 and $(b)$ those first employed before that date. Because the latter group was selected in that it excluded employees who had left before 1938, the two groups were analysed separately. In fact, the findings were similar for those two groups and are reported together in this paper.

In all, 4137 men and 998 women met the cohort criteria. We ascertained survival status as of 31 December 1977 through local inquiries and from information on deaths provided by Social Security Administration. All but 113 men (3\%) and 61 women $(6 \%)$ were traced; of those traced, 1400 men $(35 \%)$ and 170 women $(18 \%)$ had died. Copies of death certificates were obtained from state departments of vital statistics or from the country where death had occurred for 1354 (97\%) of the men and $165(97 \%)$ of the women. In two male deaths without certificate the cause was ascertained from other sources. Causes of death were coded according to the seventh revision of the International Classification of Disease (ICD) by a single qualified nosologist. This paper deals only with the 1392 male deaths, shown by age and cause in table 1. Eight deaths are omitted from this table because of insufficient information on age. Female mortality in this and the other two plants will be reported separately.

\section{THE PROCESS}

The plant was opened in a rural area of central Pennsylvania in the early 1900s. From the beginning it has manufactured a variety of products, almost all containing asbestos. The factory had a large asbestos textile division of traditional type. Crude fibre was cleaned, opened, carded on modified wool carding machines, spun using mule and later ring-type frames, and wound and woven into cloth or plyed to form tape. Much of the cloth or tape was treated with resin, dried, and then finished into brake linings, clutch facings, and transmission strips. Since the early days the plant has also manufactured friction materials by blending raw asbestos with resinbinding ingredients followed by extrusion, rolling, or bricketting.

Chrysotile, obtained mostly from Canada and Rhodesia, was the main type of asbestos processed, with some 3000 to 6000 tons of varying quality used annually. Crocidolite and amosite were used from 1924 onwards for making insulation blankets for locomotives and turbines and equipment for chemical factories, and paper mills. Amosite insulation blankets were produced in large quantities during 1942-5 to meet US naval specifications. Crocidolite packings were also produced, as were crocidolite and amosite filter materials. Much of the crocidolite was imported as yarn and only about three to five tons of raw fibre were used annually whereas, in 1943 , the use of amosite reached a peak of 600 tons. From 1925 to 1931 manufacture of insulation mattresses and filter cloth was transferred to a disused opera house in the town. The mattresses were packed with crocidolite or amosite, the crocidolite yarn being imported from England. After 1931, the opera house was used as a warehouse and the manu-

Tabie 1 Male deaths by age and certified cause

\begin{tabular}{|c|c|c|c|c|}
\hline \multirow[t]{2}{*}{ Cause of death (ICD code) } & \multicolumn{3}{|c|}{ Age at death } & \multirow[t]{2}{*}{ Total } \\
\hline & $<45$ & $45-64$ & $\geqslant 65$ & \\
\hline All causes & 191 & 667 & 534 & 1392 \\
\hline $\begin{array}{l}\text { Malignant neoplasms: } \\
\text { Lung* }(162-164) \\
\text { Oesophagus and stomach }(150-151) \\
\text { Colon and rectum }(152-154) \\
\text { Other abdominal* }(155-159) \\
\text { Larynx }(161) \\
\text { Other }(140-148,160,165-205) \\
\text { Heart disease }(400-443) \\
\text { Respiratory tuberculosis }(001-008) \\
\text { Other respiratory }(470-522,525-527) \\
\text { Pneumoconiosis }(523-524) \\
\text { Cerebrovascular }(330-334) \\
\text { Accidents (800-999) } \\
\text { Other known causes* } \\
\text { Cause not known }\end{array}$ & $\begin{array}{r}3 \\
1 \\
2 \\
3 \\
0 \\
16 \\
43 \\
5 \\
6 \\
2 \\
3 \\
74 \\
23 \\
10\end{array}$ & $\begin{array}{r}49 \\
7 \\
21 \\
16 \\
0 \\
57 \\
285 \\
4 \\
17 \\
48 \\
33 \\
44 \\
73 \\
13\end{array}$ & $\begin{array}{r}18 \\
6 \\
12 \\
5 \\
0 \\
40 \\
245 \\
2 \\
25 \\
24 \\
44 \\
20 \\
80 \\
13\end{array}$ & $\begin{array}{r}70 \\
14 \\
35 \\
24 \\
0 \\
113 \\
573 \\
11 \\
48 \\
74 \\
80 \\
138 \\
176 \\
36\end{array}$ \\
\hline
\end{tabular}

*In 13 cases in these categories, mesothelioma was given as the cause of death; in one death ascribed to asbestosis, mesothelioma was also mentioned. 
Table 2 Estimated average prevailing dust concentrations (MPCF) in main departments 1930-70

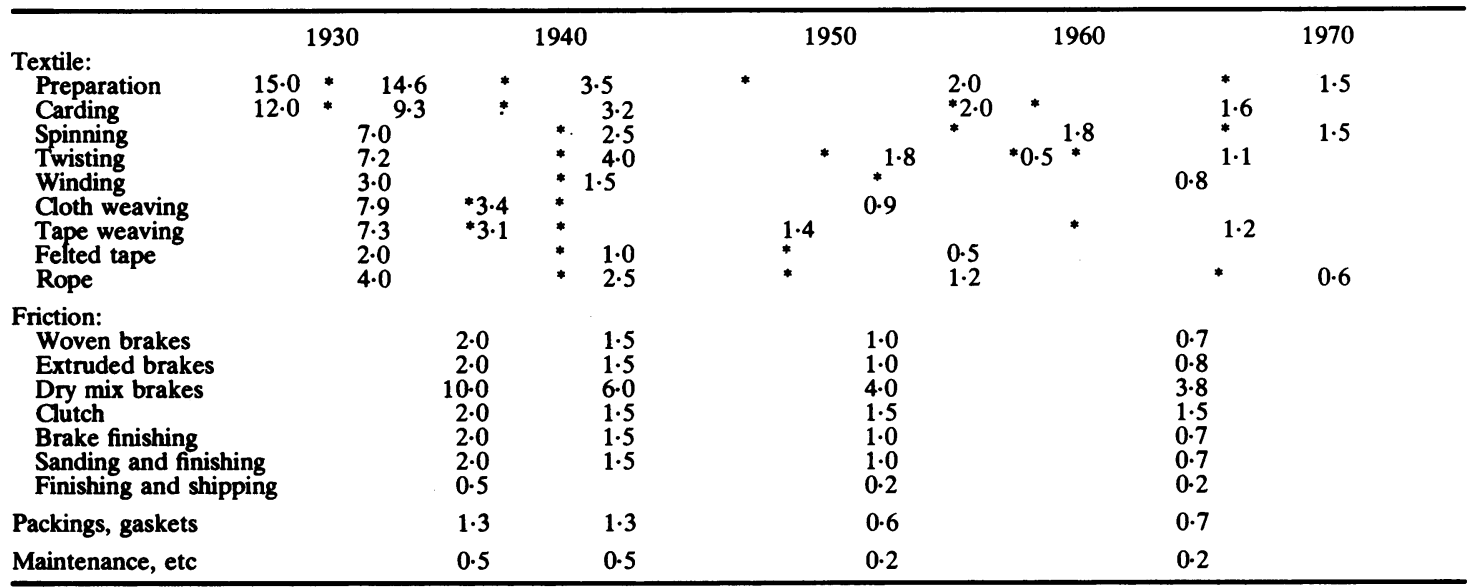

*Asterisks shown against textile processes indicate approximate date of improvements usually associated with technical change. Figures for friction and other departments are estimates for each decade.

Table 3 Age at start, duration of employment, and dust exposure (male only)

\begin{tabular}{|c|c|c|c|c|c|}
\hline & \multicolumn{5}{|c|}{ Length of gross service } \\
\hline & $<1$ & $1,<5$ & $5,<20$ & $\geqslant 20$ & Total \\
\hline $\begin{array}{l}\text { No } \\
\text { Average age at start (years) } \\
\text { Gross service (years) } \\
\text { Net service (years) } \\
\text { Average dust concentration (mpcf) }\end{array}$ & $\begin{array}{r}1248 \\
28 \cdot 80 \\
0 \cdot 40 \\
0 \cdot 38 \\
2 \cdot 60\end{array}$ & $\begin{array}{r}906 \\
29 \cdot 30 \\
2 \cdot 39 \\
1.87 \\
2.40\end{array}$ & $\begin{array}{r}855 \\
30 \cdot 77 \\
11 \cdot 01 \\
8 \cdot 06 \\
2 \cdot 73\end{array}$ & $\begin{array}{r}1013 \\
27 \cdot 22 \\
30 \cdot 63 \\
27 \cdot 51 \\
1 \cdot 58\end{array}$ & $\begin{array}{r}4022^{*} \\
28 \cdot 92 \\
10 \cdot 71 \\
9 \cdot 18 \\
2 \cdot 32\end{array}$ \\
\hline
\end{tabular}

*Excluding two whose employment histories were incomplete.

facture of cloth and mattresses was returned to the main site.

\section{EXPOSURE}

Conditions are reported to have been very dusty in the 1920 and 1930s, although oil spraying introduced to facilitate handling probably had some damping effect. The first steps to reduce exposure were taken in 1930; these included wetting, improved handling methods, and ventilation hoods. By about 1939 exhaust ventilation had been installed in the textile mill with substantial reduction in dust levels; thereafter improvement was gradual.

Reports of surveys made by the Metropolitan Life Insurance Company in the period 1930-9 were available, as were surveys by the United States Public Health Service made in 1967 and in 1970. Measurements were made routinely by the company from 1956 onwards. Until 1967, all measurements were made by impinger and recorded in millions of particles per cubic foot (mpcf). Dust level estimates for each department were made by the hygienist of our group (AJW) and are summarised in table 2 . These estimates do not take into account certain additional exposures which may have been quite short but which were certainly very heavy. These were associated with daily "blowing down" and "whipping the burlap" in the dust house. At weekends waste asbestos thus recovered in the dust house was swept up and bagged for recycling. A new dust collection system introduced in the early 1950 s virtually removed this hazard.

The data available on exposure are summarised in table 3, grouped by duration of employment. The average age at start of work and the average dust concentration differed little in the four duration groups.

\section{STATISTICAL METHODS}

Mortality in the cohort was analysed $(a)$ by the man-years life table method of Hill, ${ }^{6}$ using Pennsylvania death rates for reference, and $(b)$ by the log rank procedure of Mantel and Heanszel, ${ }^{7}$ exactly as in the South Carolina study. ${ }^{2}$

\section{Results}

The standardised mortality ratio (SMR) for all 
Table 4 Male deaths 20 years after first employment, by cause, in relation to length of service

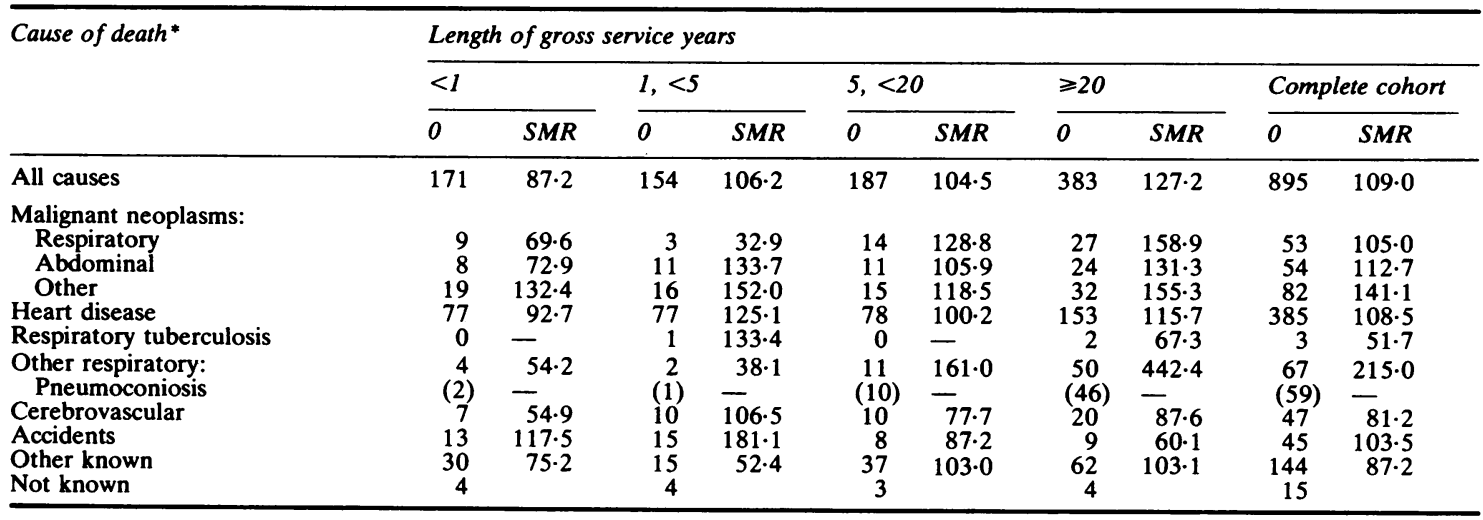

*As in table 1 except that ICD codes 160-164 are here grouped under "respiratory" malignnt neoplasms and the "other respiratory" category includes only bronchitis, pneumonia, and pneumoconiosis (ICD 490-502, 523-4).

Table 5 Male deaths 20 years after frst employment, by cause, in relation to dust exposure (mpcf.y) accumulated to 10 years before death

\begin{tabular}{|c|c|c|c|c|c|c|c|c|c|c|}
\hline \multirow{3}{*}{$\begin{array}{l}\text { Cause of death* } \\
\text { (See table 4) }\end{array}$} & \multicolumn{10}{|c|}{ Dust exposure (mpcf.y) } \\
\hline & \multicolumn{2}{|c|}{$<10$} & \multicolumn{2}{|c|}{$10<20$} & \multicolumn{2}{|c|}{$20<40$} & \multicolumn{2}{|c|}{$40<80$} & \multicolumn{2}{|l|}{$\geqslant 80$} \\
\hline & 0 & $S M R$ & 0 & $S M R$ & 0 & $S M R$ & 0 & $S M R$ & 0 & $S M R$ \\
\hline All causes & 470 & $93 \cdot 1$ & 86 & $82 \cdot 1$ & 130 & $125 \cdot 6$ & 105 & $174 \cdot 9$ & 104 & $215 \cdot 2$ \\
\hline $\begin{array}{l}\text { Malignant neoplasms: } \\
\text { Respiratory } \\
\text { Abdominal } \\
\text { Other } \\
\text { Heart disease } \\
\text { Respiratory tuberculosis } \\
\text { Other respiratory: } \\
\text { Pneumoconiosis } \\
\text { Cerebrovascular } \\
\text { Accidents } \\
\text { Other known } \\
\text { Not known }\end{array}$ & $\begin{array}{r}21 \\
26 \\
47 \\
221 \\
1 \\
8 \\
(4) \\
27 \\
33 \\
74 \\
12\end{array}$ & $\begin{array}{r}66.9 \\
90.2 \\
130.4 \\
102.7 \\
34.3 \\
43.6 \\
-78.3 \\
120.1 \\
73.3\end{array}$ & $\begin{array}{r}5 \\
8 \\
5 \\
41 \\
0 \\
5 \\
(1) \\
1 \\
3 \\
17 \\
1\end{array}$ & $\begin{array}{r}83.6 \\
130.5 \\
68.5 \\
89.2 \\
- \\
122.0 \\
-13.3 \\
56.2 \\
80.0\end{array}$ & $\begin{array}{c}10 \\
5 \\
11 \\
60 \\
-10 \\
(9) \\
10 \\
1 \\
23 \\
0\end{array}$ & $\begin{array}{r}156.0 \\
79.7 \\
148.6 \\
130.6 \\
- \\
263.0 \\
\overline{133.5} \\
18.6 \\
109.7\end{array}$ & $\begin{array}{r}6 \\
8 \\
7 \\
34 \\
1 \\
14 \\
(9) \\
8 \\
6 \\
21 \\
0\end{array}$ & $\begin{array}{l}160 \cdot 0 \\
218.8 \\
164.7 \\
130.5 \\
169.7 \\
623.3 \\
\overline{187.2} \\
193.9 \\
172.2\end{array}$ & $\begin{array}{c}11 \\
7 \\
12 \\
29 \\
1 \\
30 \\
(36) \\
1 \\
2 \\
9 \\
2\end{array}$ & $\begin{array}{l}416 \cdot 1 \\
237.2 \\
372.8 \\
108 \cdot 5 \\
163.6 \\
1689.2 \\
-\quad \\
29.3 \\
91.0 \\
97.8\end{array}$ \\
\hline
\end{tabular}

Table 6 Dust exposure in male deaths from selected causes and controls (Mantel-Haenszel analysis ${ }^{8}$ )

\begin{tabular}{|c|c|c|c|c|c|c|c|}
\hline & \multicolumn{5}{|c|}{$\begin{array}{l}\text { Dust exposure (mpcf.y) accumulated up } \\
\text { to } 10 \text { years before death of case }\end{array}$} & \multirow[t]{2}{*}{$\begin{array}{l}\text { Chi square } \\
\text { Difference }\end{array}$} & \multirow[t]{2}{*}{ Linearity } \\
\hline & $<10$ & $10<20$ & $20<40$ & $40<80$ & $\geqslant 80$ & & \\
\hline $\begin{array}{l}\text { Pneumoconiosis } \\
\text { Deaths } \\
\text { Expected } \\
\text { Relative risk }\end{array}$ & $\begin{array}{c}3 \\
14 \cdot 6 \\
1\end{array}$ & $\begin{array}{l}4 \\
8 \cdot 1 \\
4 \cdot 04\end{array}$ & $\begin{array}{c}10 \\
10.9 \\
13.72\end{array}$ & $\begin{array}{c}11 \\
8 \cdot 1 \\
14 \cdot 93\end{array}$ & $\begin{array}{c}28 \\
14 \cdot 3 \\
37 \cdot 90\end{array}$ & 39.56 & $39 \cdot 17$ \\
\hline $\begin{array}{l}\text { Lung cancer (IC } \\
\text { Deaths } \\
\text { Expected } \\
\text { Relative risk }\end{array}$ & $\begin{array}{l}20 \\
24 \cdot 4 \\
1\end{array}$ & $\begin{array}{l}4 \\
5 \cdot 2 \\
0.83\end{array}$ & $\begin{array}{l}10 \\
8.0 \\
1.54\end{array}$ & $\begin{array}{l}6 \\
5 \cdot 6 \\
2 \cdot 90\end{array}$ & $\begin{array}{c}11 \\
7.7 \\
6.82\end{array}$ & $5 \cdot 77$ & $4 \cdot 98$ \\
\hline $\begin{array}{l}\text { Abdominal canc } \\
\text { Deaths } \\
\text { Expected } \\
\text { Relative risk }\end{array}$ & $\begin{array}{l}26 \\
28 \cdot 8 \\
1\end{array}$ & $\begin{array}{l}8 \\
6 \cdot 8 \\
1 \cdot 15\end{array}$ & $\begin{array}{l}5 \\
7 \cdot 0 \\
0 \cdot 66\end{array}$ & $\begin{array}{l}8 \\
5 \cdot 3 \\
2 \cdot 45\end{array}$ & $\begin{array}{l}7 \\
6 \cdot 1 \\
2 \cdot 85\end{array}$ & $3 \cdot 22$ & 1.09 \\
\hline $\begin{array}{l}\text { All causes } \\
\text { Deaths } \\
\text { Expected } \\
\text { Relative risk }\end{array}$ & $\begin{array}{c}451 \\
476 \cdot 6 \\
1\end{array}$ & $\begin{array}{c}81 \\
104 \cdot 5 \\
0.82\end{array}$ & $\begin{array}{l}121 \\
118 \cdot 6 \\
1 \cdot 20\end{array}$ & $\begin{array}{r}100 \\
80.4 \\
1.6\end{array}$ & $\begin{array}{l}99 \\
72 \cdot 0 \\
2 \cdot 12\end{array}$ & $34 \cdot 66$ & $26 \cdot 12$ \\
\hline
\end{tabular}


causes of death was 109.0. Those employed for under one year had an SMR of $87 \cdot 2$, and those who had worked 20 or more years, $127 \cdot 2$ (table 4). Malignant neoplasms, heart disease, and "other respiratory" disease were mainly responsible for the higher SMR in these long term workers. The other respiratory category included bronchitis and pneumonia (ICD 470-502) and pneumonoconiosis (ICD 523-4) and was chosen for study because expected figures for pneumoconiosis alone were not available. Table 5 shows SMRs by cause and by accumulated dust exposure. The SMR for all causes rose steadily from 93.1 for men with an exposure at under 10 mpcf.y to 215.2 in the highest category ( $\geqslant$ 80 mpcf.y). Respiratory, abdominal, and other malignant disease and the non-malignant other respiratory group all contributed to this rising trend. On 14 death certificates a diagnosis of mesothelioma was specified: 10 were pleural tumours and four peritoneal. These deaths occurred in the period 1960-75. One (in 1960) was 16 years after first employment; the remaining 13 occurred 25-53 years after first employment. Two of the deaths from mesothelioma had been given the ICD code 199 (malignant neoplasms of other and unspecified sites); another 30 deaths 15 more years after first employment were given the code 199. Seventeen of these 30 deaths occurred before 1965 , the year after which most of the deaths from mesothelioma occurred. The diagnosis given in many of these cases was consistent with an unrecognised peritoneal mesothelioma.

The Mantel-Haenszel (log rank) analysis (table 6) bore out the exposure-response relationships observed in table 5 . There is a small shortfall $(5 \%$ overall) between the numbers of cases used in this analysis and in the man-years analyses presented in tables 4 and 5 . The deficiency is explained by failure to find matching controls for every selected case.

\section{Discussion}

The present cohort in the Pennsylvania plant was constituted in exactly the same way as that in the South Carolina chrysotile textile plant described elsewhere. ${ }^{2}$ Compared with the South Carolina employees (see table 3), those in Pennsylvania had worked for similar periods but were on average some four years older when they started work (28.93 years compared with 25.08 years). The Pennsylvania cohort was exposed to a somewhat higher average dust concentration: $2.32 \mathrm{mpcf}$ compared with 1.80 mpcf in South Carolina. The mortality pattern in Pennsylvania resembled that in South Carolina in showing a rising SMR with increasing dust exposure for all causes of death, for respiratory cancer, and for pneumoconiosis. For respiratory cancer, however, the SMR for the lowest exposure group (less than 10 mpcf.y) was 115.5 in South Carolina but only 69.9 in Pennsylvania. By contrast with South Carolina, where the SMRs tended to be above 100 for causes unrelated to asbestos, and for all causes in very short term employees, ${ }^{2}$ the opposite was true in Pennsylvania. It seems likely that in both cohorts lack of comparability with the relevant state populations may be the explanation. Having regard for this possibility, the use of relative risks is perhaps more appropriate than SMRs for comparing the respiratory cancer mortality of the two cohorts. Table 7 shows that the relative risks of death from all causes, respiratory cancer, and pneumoconiosis in the two plants were extraordinarily similar. In both cohorts the relationships of respiratory cancer to exposure were essentially linear (figure) with slopes that were nearly identical (South Carolina, $\mathrm{RR}=1+0.059$ mpcf.y; Pennsylvania, RR $=1+$ 0.051 mpcf.y).

A conceivable explanation for depression of the SMRs in the Pennsylvania plant was that the em-

Table 7 Relative risks based on SMRs by cumulative exposure in two plants

\begin{tabular}{|c|c|c|c|c|c|}
\hline & \multicolumn{5}{|c|}{ mpcf.y } \\
\hline & $<10$ & $10<20$ & $20<40$ & $40<80$ & $\geqslant 80$ \\
\hline $\begin{array}{l}\text { All causes: } \\
\text { South Carolina plant } \\
\text { Pennsylvania plant }\end{array}$ & $\begin{array}{l}1 \cdot 0 \\
1.0\end{array}$ & $\begin{array}{l}1.09 \\
0.88\end{array}$ & $\begin{array}{l}1.36 \\
1.35\end{array}$ & $\begin{array}{l}1.48 \\
1.88\end{array}$ & $\begin{array}{l}2.29 \\
2.31\end{array}$ \\
\hline $\begin{array}{l}\text { Respiratory cancer } \\
\text { South Carolina plant } \\
\text { Pensylvania plant }\end{array}$ & $\begin{array}{l}1 \cdot 0 \\
(1 \cdot 32) \\
1 \cdot 0 \\
(1 \cdot 26)\end{array}$ & $\begin{array}{l}1.28 \\
(1.68) \\
1.25 \\
(1.58)\end{array}$ & $\begin{array}{l}2 \cdot 13 \\
(2 \cdot 80) \\
2 \cdot 33 \\
(2 \cdot 94)\end{array}$ & $\begin{array}{l}2.93 \\
(3 \cdot 86) \\
2 \cdot 39 \\
(3.03)\end{array}$ & $\begin{array}{c}7 \cdot 21 \\
(9.49) \\
6 \cdot 22 \\
(7 \cdot 87)\end{array}$ \\
\hline $\begin{array}{l}\text { Bronchitis, pneumonia, } \\
\text { pneumoconiosis: } \\
\text { South Carolina plant } \\
\text { Pennsylvania plant }\end{array}$ & $\begin{array}{l}1.0 \\
1.0\end{array}$ & $\begin{array}{l}1.81 \\
2.79\end{array}$ & $\begin{array}{l}6.40 \\
6.03\end{array}$ & $\begin{array}{l}21 \cdot 36 \\
14 \cdot 29\end{array}$ & $\begin{array}{l}19.67 \\
38.74\end{array}$ \\
\hline
\end{tabular}

Figures in italics are relative risks calculated from SMRs at zero exposure derived from fitted line. 


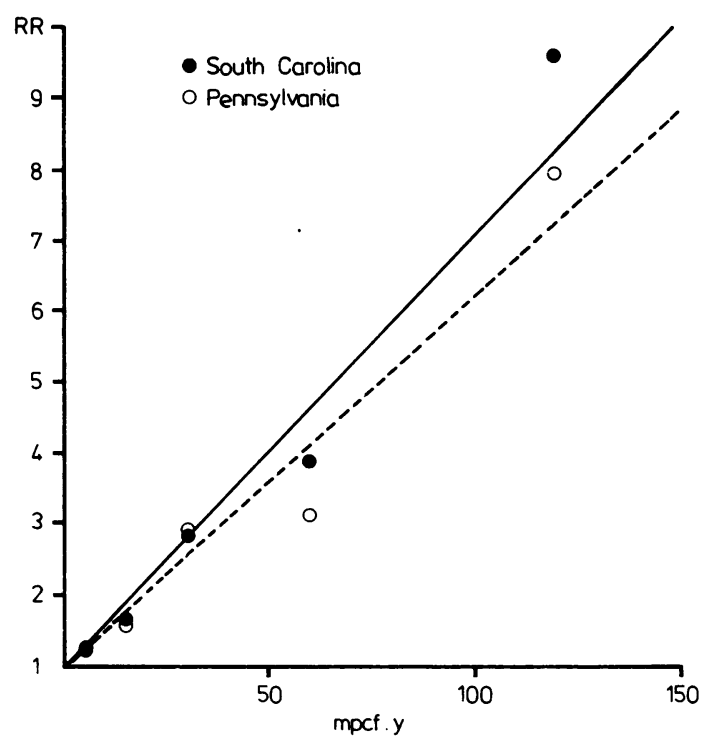

Relative risk of respiratory cancer and accumulated dust exposure in two mainly textile plants. (Lines fitted by FI) K Liddell using the methods of Hanley and Liddell.)

ployees had smoked fewer cigarettes than the general population of the state, perhaps because of the high proportion of Mennonites in the local community. We ascertained, however, that in fact very few Mennonites were employed in the plant. Smoking histories had been recorded in a standard manner for all those at work in 1978 or later in the two plants and also in the plant in Connecticut where the third cohort was studied. ${ }^{3}$ Of men born in 1910-9 (who would have been included in the three cohorts) the proportions who had never smoked were: $25 \%$ (of 36) in Pennsylvania, 11\% (of 95) in South Carolina, and $16 \%$ (of 206) in Connecticut. Thus the proportion of non-smokers (25\%), though somewhat higher than in the other two cohorts, is based on very small numbers and no firm conclusion can be drawn.

Similar proportions of all deaths in the two cohorts were from malignant disease $(17 \%$ in South Carolina and $18 \%$ in Pennsylvania) but the types of malignancy differed. In South Carolina respiratory cancer accounted for $47 \%$, abdominal $25 \%$, and other types $28 \%$ whereas in the Pennsylvania plant the corresponding proportions were reversed, $27 \%$, $29 \%$, and $44 \%$. Moreover, in South Carolina no systemic relationship with exposure was seen for abdominal or other types of malignant disease whereas in Pennsylvania there was evidence of such a relationship.

The increased risk of mesothelioma in the Penn- sylvania plant (14 cases in 1392 male deaths $(1 \%)$ compared with one case in $867(0.1 \%)$ in South Carolina) raises the question of whether the abdominal and more particularly other types of cancer included undiagnosed cases of mesothelioma. There is some support for this idea in the substantial number coded to ICD 199 (malignant disease of other and unspecified sites) and the fact that 17 of these deaths occurred before 1964 when malignant mesothelioma started to become more generally recognised. Once again we find evidence in this study of the special risk of mesothelioma associated with exposure to even quite small proportions of amphibole, in this case predominantly amosite.

The very similar exposure-response relationships for respiratory cancer and asbestosis observed in this and the South Carolina plant support our previous conclusion that the risks of these diseases in chrysotile production (mining and milling) and in textile manufacture are quite different. In the third plant studied, a friction materials plant in Connecticut, there was little or no excess risk of respiratory cancer or asbestosis. ${ }^{3}$ This was also true in a friction materials plant in the United Kingdom. ${ }^{9}$ Possible reasons for the striking epidemiological differences-fibre size distributions in particularhave been discussed elsewhere. ${ }^{210}$

Many people and organisations helped in most aspects of this research. We thank especially Sheryl Nixon for data processing and Roslyn MacNish for coding causes of death. A grant toward the cost of the study was made to St Mary's Hospital Medical School by the Institute of Occupational and Environmental Health of the Quebec Asbestos Mining Association. Facilities for completing the study were given to Dr A D McDonald by the Institut de Recherche en santé et en sécurité du Québec.

Requests for reprints to: Dr J C McDonald, School of Occupational Health McGill University, 1130 Pine Avenue West, Montreal, Canada H3A 1A3.

\section{References}

${ }^{1}$ McDonald AD, Fry JS. Mesothelioma and fibre type in three American asbestos factories. Preliminary report. Scand J Work Environ Health 1982;8 supple:53-8.

${ }^{2}$ McDonald AD, Fry JS, Woolley AJ, McDonald JC. Dust exposure and mortality in an American chrysotile textile plant. Br J Ind Med 1983;40:361-67.

${ }^{3}$ McDonald AD, Fry JS, Woolley AJ, McDonald JC. Dust exposure and mortality in an American chrysotile friction products plant. $\mathrm{Br} J$ Ind $\mathrm{Med}$ (in press).

4 Mancuso TF, Et Attar AA. Mortality pattern in a cohort of asbestos workers. JOM 1967;9:147-62.

${ }^{5}$ Robinson C, Lemen R, Wagoner J. Mortality patterns 
1940-1975 among workers employed in an asbestos textile friction and packing products manufacturing facility. In: Lemen R, Dement JM, eds. Dusts and diseases. Park Forest South, Illinois: Pathotox Publishers, Inc, 1979:131-43.

- Hill ID. Computing man years at risk. Br J Prev Soc Med 1972;26:132-4.

' Mantel N, Haenszel W. Statistical aspects of the analysis of data from retrospective studies of disease. $J$ Natl Cancer Inst 1959;22:719-48.
${ }^{8}$ Peto R, Pike MC. Conservation of the approximation E (Q$E)^{2} / E$ in the log rank test for survival data or tumor incidence data. Biometrics 1973;29:579-84.

${ }^{9}$ Newhouse ML, Berry G, Skidmore JW. A mortality study of workers manufacturing friction materials with chrysotile asbestos. Ann Occup Hyg 1982;26:899-909.

${ }^{10} \mathrm{McDonald}$ JC. Aspects of the asbestos standard. In: Gee JBL, Morgan KC, Brooks SM, eds. Occupational lung disease. New York: Raven Press, 1983. 